INTERACTION: Jurnal Pendidikan Bahasa; Vol. 7, No. 1; Mei 2020

ISSN: 2406-9558; E-ISSN: 2406-9566

\title{
Online Game towards the Students' Vocabulary of Technology and Information Department at UNIMUDA Sorong
}

\author{
Rizqi Claudia Wardani.H \\ rizqiclaudiawardani@gmail.com \\ Isnaini Eddy Saputro \\ isnaini1712@gmail.com \\ Siti Zuhriyanti Rusli \\ qurrotaayuun97@gmail.com
}

\section{Universitas Pendidikan Muhammadiyah Sorong}

\begin{abstract}
The objective of this research is to know whether there is any significant influence of using game online and improvement of the students' vocabulary of Technology and Information Department at UNIMUDA Sorong. This research was quantitative research. The researcher used preexperimental research design. The population was the student of technology and Information. The sample were first, third, and fifth semesters. The researcher ask the student to play the game with English instruction and search the new word that they don't know before. Researcher used test (pretest and post-test) as the instrument in collecting data. The test consisted 20 question which is divided into multiple choice, matching, gap in the filling and making sentences form. The researcher analyzed the data using SPSS 22.0 for Windows. The result of data analysis using SPSS 22.0, the researcher gave interpretation toward " $\mathrm{t}$ " score by comparing t-value or tcount with $\mathrm{t}$-table. The researcher interpretation that $\mathrm{t}$-value (-7.121) with the significant value is 0.000 . The score of t-table is $(1,729)$ with significant level of 0.05 with $\mathrm{df} 19$. It is known that t-value is higher than t-table (7.121> 1,729) and $\mathrm{P}$ value smaller than 0,05 . Therefore, there is a significant influence of using game online to improve the students' vocabulary of Technology and Information Department at UNIMUDA Sorong.
\end{abstract}

Keywords: Online Game, Vocabulary 
INTERACTION: Jurnal Pendidikan Bahasa; Vol. 7, No. 1; Mei 2020

ISSN: 2406-9558; E-ISSN: 2406-9566

\section{INTRODUCTION}

Learning English related with vocabulary. According to Agnieszka Uberman (2008) vocabulary acquisition is increasingly viewed as crucial to language acquisition. In order to build a house, you will need bricks. To build a language, you will need words. Words here would mean vocabulary and vocabulary is a vital element in language learning. Especially for beginners, vocabulary mastery is the very basic knowledge to learn more about English. Vocabulary is very important in learning English. Vocabulary is one of the keys to be successful in mastering English (Nurteteng \& Nopitasari, 2019). It is a central to English language teaching because without sufficient vocabulary students cannot understand others or express their own ideas.

Cameron (2001) added that Foundation to learn foreign language is by building up a useful vocabulary. Vocabulary leads to a fluent speaking skill. Lack of vocabulary can make the people do not understand and can not speak English, and to improve English language not only in the formal class but also in a course. In general, teaching vocabulary especially for young learners is not easy. Teachers need more creativity in presenting it. It can be with self-taught like by talking with a tourist, English song, and also a game that use English instruction.

Online game is one of solution for teaching vocabulary in this technology era. Nursalim, Wardani H, \& Karraske (2018) said that using game can make some atmosphere to push the student hopes in learning language. Learning vocabulary through games has gained much attention from language researchers. Donmus (2010) believes that implementing games into parts of education has been shown to improve student language vocabulary mastery while making language education seem enjoyable (p. 1497). This is relevant to the opinion of Kuzu and Ural (cited in Donmus., 2010, p. 1499) that when games and education are combined, they synergize with entertaining education. Students who learn through the use games produce positive moods and attitudes and students are more motivated studying time. Yip and Kwan (2006) in their study sound that learners playing online vocabulary games tend to learn more appropriately and could retain the new words for a longer period of time and retrieve more words compared to those who aren't provided with vocabulary games. Hence, the writer intend to know the effect of online game toward the students' vocabulary especially for the students at Technology and Information department. 
INTERACTION: Jurnal Pendidikan Bahasa; Vol. 7, No. 1; Mei 2020

ISSN: 2406-9558; E-ISSN: 2406-9566

\section{LITERATURE REVIEW}

\section{Previous of Study}

Ashraf, Motlagh \& Salami (2014) reports the usefulness of online games in vocabulary learning of Iranian EFL students. The participants, (24) low-intermediate EFL learners, were randomly assigned to experimental and control groups. The experimental group learnt some new words via online computer games in 15 weeks. A vocabulary-based test, acting as pre-test and posttest, was conducted in the first and 15th weeks. The findings of the analyzed data indicated that the experimental group outperformed the control group statistically significant in the post-test. Therefore, on line games proved to be more effective in learning English vocabulary for these students.

Florence \& Alvin (2006), reports a study of the usefulness of online games in vocabulary learning for some undergraduate students. Three teachers and 100 engineering students participated in a quasi-experimental study for approximately nine weeks. The experimental group learnt some vocabulary from two carefully selected web sites with games, while the control group learnt the same vocabulary through activity-based lessons. A pre-test and post-test were conducted in the first and ninth weeks. The findings indicate that the experimental group outperformed the control group statistically in the post-test. The students in the experimental group generally preferred online learning supplemented with digital educational games to conventional activity-based lessons. The teachers thought highly of the online games, but they expressed concern that extra support was required if the online games were adopted as a core part of their teaching.

\section{Vocabulary}

Vocabulary is the collection of words that an individual knows (License, 2005). There are some expert who give definitions of vocabulary. According Hornby (2006: 1645) vocabulary is all the words that a person knows or uses and it is all the words in a particular language. Jackson and Amvela (2000:11) say that the terms of vocabulary, lexis, and lexicon are synonymous. Furthermore, Jackson and Amvela (2000: 11) say that the terms vocabulary, lexis, and lexicon are synonymous. In addition, Richards and Schmidt (2010) state that vocabulary is a set of lexeme, including single words, compound words, and idioms. Vocabulary is define as a list or collection of words usually alphabetically arranged and explained or lexicon, stock of words use in language or by class, individual, etc. So, definition of vocabulary is the collection word and a particular language that when the people can make it to be a sentences.

Thornbury (2002: 2) states that the condition should help learners to acquire a critical mass of words to use in both understanding and producing language. Vocabulary is vital to communicating with others and understanding what one is reading. Many words 
have several different meanings; one must study the meanings of the words and the part of speech, the words in context etc. Apply what you learn by writing sentences with your words. If one's vocabulary is very strong, it will help the person to write accurately and speak fluently. It is very important and vital while communicating with others. Hence, Words, or phrases or group of words can be termed as vocabulary. Vocabulary includes synonyms, idioms, antonyms or word lists.

\section{Online Games (PUBG Game)}

Games can be helpful for teachers in creating contexts where language is useful and meaningful. Wright, Betteridge and Buck (cited in Rohani \& Pourgharib., 2013, p. 3541) believe that "By using games, teachers can create various contexts in which students must use language to communicate, exchange information and express their own opinions. To effectively promote learning, the game must include ways for students to reflect on and explain what is happening.

Player Unknown's Battlegrounds (PUBG) is an online multiplayer battle royal game developed and published by PUBG Corporation, a subsidiary of South Korean video game company Bluehole. The game is based on previous mods that were created by Brendan "PlayerUnknown" Greene for other games, inspired by the 2000 Japanese film Battle Royale, and expanded into a standalone game under Greene's creative direction. In the game, up to one hundred players parachute onto an island and scavenge for weapons and equipment to kill others while avoiding getting killed themselves.

The available safe area of the game's map decreases in size over time, directing surviving players into tighter areas to force encounters. The last player or team standing wins the round. Battlegrounds is a player versus player shooter game in which up to one hundred players fight in a battle royal, a type of large-scale last man standing death match where players fight to remain the last alive. Players can choose to enter the match solo, duo, or with a small team of up to four people. The last person or team alive wins the match. Each match starts with players parachuting from a plane onto one of the four maps, with areas of approximately $8 \times 8$ kilometers $(5.0 \times 5.0 \mathrm{mi}), 6 \times 6$ kilometers $(3.7 \times 3.7 \mathrm{mi})$, and $4 \times 4$ kilometers $(2.5 \times 2.5 \mathrm{mi})$ in size. The plane's flight path across the map varies with each round, requiring players to quickly determine the best time to eject and parachute to the ground.

\section{METHOD}

\section{Design and Sample}

This study used quantitative approach. Pre-experimental research design was used in this study. The sample of this research was the students of Technology and Information 
Department who like to play PBUG online game. They are taken with purposive sampling where the researcher only choose the students who want to be the sample of this research. There were 20 students who were involved in this research.

\section{Instrument and Procedure}

Vocabulary test was used as an instrument. It consist of 5 items multiple choice, 5 items gap filling, 5 items matching, and 5 items making sentences. It administered to the students in pretest and post-test. After giving the pretest, the researcher gave the treatment during six meetings. Each meeting the students played the game of PUBG and the researcher taught them the new vocabulary which is found in the game. The students also get studied making sentence from the vocabulary found.

\section{Analysis Data}

After collecting the data, pre-test and post-test from the experimental group, then the researcher measured the score differences from pre-test and post-test of experimental group by the statistical calculation. In this study, the researcher used SPSS to find out whether the mean differences and significant or not. After the researcher counted the correct answer from each question, the researcher used the SPSS 22 to analysis the data. The analysis data there are Normality test and Paired Sample T-test.

\section{RESULT AND DISCUSSION}

After giving pre-test and post-test, the researcher calculated the score of students between pre-test and post-test. The result of the study has been categorized in the following table:

\section{Table 1.}

The Result of the Students'Score between Pretest and Posttest

\begin{tabular}{|c|c|c|c|c|c|}
\hline \multirow{2}{*}{ The Score } & \multirow{2}{*}{ Categories } & \multicolumn{2}{|c|}{ Pretest } & \multicolumn{2}{c|}{ Posttest } \\
\cline { 3 - 6 } & & $\mathrm{F}$ & $\mathrm{P}$ & $\mathrm{F}$ & $\mathrm{P}$ \\
\hline $80-100$ & Very Good & 4 & $20 \%$ & 15 & $75 \%$ \\
\hline $66-79$ & Good & 3 & $15 \%$ & 1 & $5 \%$ \\
\hline $56-65$ & Sufficient & 3 & $15 \%$ & 4 & $20 \%$ \\
\hline $40-55$ & Less Good & 7 & $35 \%$ & - & - \\
\hline$<30-39$ & Fail & 3 & $15 \%$ & - & - \\
\hline \multicolumn{2}{|c|}{ Total } & 20 & $100 \%$ & 20 & $100 \%$ \\
\hline
\end{tabular}


In pretest, there are 3 students (15\%) of them categorized into fail, 7 students $(35 \%)$ of them categorized into less good, 3 students (15\%) of them categorized into sufficient, 3 students $(15 \%)$ of them categorized into good, 4 students $(20 \%)$ of them categorized into very good. Whereas in post-test, no one categorized into fail and less good score. There are 4 students $(20 \%)$ of them categorized into sufficient score, 1 student $(5 \%)$ of them categorized into good score and 15 students (75\%) of them categorized very good score.

The researcher calculating the data on SPSS 22.0 for Windows. On the descriptive statistics, it shown that the data of pretest the mean score is 56.55. From the data of post test the mean score is 83.10 . The difference from pretest and posttest was 26.55 and it means that the student vocabulary after treatment was improved. Then on the test normality that the significance value from pretest is $(0 . .413<0.05)$, then the significance value from posttest is $(0.019<0.05)$. The pre-test significance value higher than 0.05 , and the post-test significance value less than 0.05 . It mean that the data non normal. After that, the researcher analyze the post-test and the result is the $t$ value $(-7.134)>\mathrm{t}$ - table $(3.883)$ and $\mathrm{P}$-value $(0,000)<0,05$. It can be concluded that there is a significance score of the students between pretest and posttest. In other word, PUBG game effect the students' vocabulary.

This finding related with Arianti and Nurnaningsih (2018) research which investigated about the effect of COC game application to 4th grade students of Jombor Sukoharjo Elementary School on the students' vocabulary. The result showed that the level of students' vocabulary mastery increased. They not only know the vocabulary around them but they also know the vocabulary through games. Another findings also was researched by Arisandi \& Itsnan (2018) who studied about The correlation between playing online game English version and students English achievement at third grade of Vocational Senior High School 3 Pemekasan. The researchers conclude that there is correlation between playing game online and student's English achievement at the third grade of Vocational Senior High School 3 of Pamekasan.

There are some factors that support the increase of the students' vocabulary using this PUBG Game. First, the games is the international game so the student can meet with another people in the game so they can learn to speak with them. Second, it has voice note to give information to their teammate which they can listen and remember the word by themselves. Third, vocabulary in this game are so many. Hence, the students can get the new vocabulary when they playing the game.

Wright, Betteridge and Buck cited in Rohani \& Pourgharib (2013) said that by using games, teachers can create various contexts in which students must use language to communicate, exchange information and express their own opinions. To effectively promote learning, the game must include ways for students to reflect on and explain 
INTERACTION: Jurnal Pendidikan Bahasa; Vol. 7, No. 1; Mei 2020

ISSN: 2406-9558; E-ISSN: 2406-9566

what is happening so the student can get a lot of vocabulary with the interest learning and this online game can be one way to improve students' vocabulary.

\section{CONCLUSION}

Based on the result of data analysis, the writer concluded that there is any sigficance influence of using Game Online to improve the student vocabulary of Technology and information Department at UNIMUDA Sorong. The results of the students' achievements in vocabulary before taught using game online is only 56.55 and it improved a lot after giving the treatment that is reached 83.10 score. It means that using Game Online is effective to improve students' vocabulary in Technology and Information Department at UNIMUDA Sorong.

\section{REFERENCE}

Arianti. and Nurnaningsih P.I. (2018). Learning English Vocabulary through Online Games: Case Study of Students in 4th Grade of State Elementary School (SDN) Jombor 01, Sukoharjo, Central Java,Indonesia. International Journal of Multicultural and Multireligious Understanding, 5 (4).

Arisandi. and Itsnan. (2016). The correlation between playing online game english version and students english achievement at third grade of vocational senior high school 3 pemekasan. Jurnal pemikiran pendidikan penelitian dan sains, 4 (2).

Ashraf, H., Motlagh, G.F., \& Salami, M. (2014). The Impact of Online Games on Learning English Vocabulary by Iranian (Low-intermediate) EFL Learners. Social and Behavioral Sciences, 98 (14), 286 - 291.

Cameron, L. (2001). Teaching Languages to Young Learners. Cambridge: Cambridge University Press.

Florence W. M. Yip \& Alvin C. M. Kwan (2006) Online vocabulary games as a tool for teaching and learning English vocabulary. Educational Media International, 43 (3), 233-249, DOI: 10.1080/09523980600641445.

Hornby, A. S. 2006. Oxford Advanced Learner's Dictionary. Oxford: Oxford University Press.

Jackson, H. \& Amvela, E. Z. 2000. Words, Meaning, and Vocabulary: An Introduction to Modern English Lexicology. New York: Cromwell Press.

Linse, C. (2005). Practical English Language Teaching: Young Learners. New York: Cromwell Press. 
INTERACTION: Jurnal Pendidikan Bahasa; Vol. 7, No. 1; Mei 2020

ISSN: 2406-9558; E-ISSN: 2406-9566

Nurteteng, N., \& Nopitasari, D. (2019). The Use of Crossword Puzzle towards the Students Vocabulary. INTERACTION: Jurnal Pendidikan Bahasa, 6(1), 9-17. https://doi.org/10.36232/jurnalpendidikanbahasa.v6i1.284

Rohani, M., \& Pourgharib, B. (2013).The effect of games on learning vocabulary. International Research Journal of Applied and Basic Sciences, 4 (11), 3540-3543.

Richard, J., \& Schmitt, N. (2010). Researching Vocabulary: A Vocabulary Research Manual. New York: Palgrave Macmillan.

Thornbury, S. (2002). How to teach vocabulary. United Kingdom: Pearson Education Limited.

Yip, F.W.M., \& Kwan, A.C.M.(2006). Online vocabulary games as a tool for teaching and Learning English vocabulary. Retrieved from: wiki.umd.edu/teamill/images/9/9f/Vicki's_article 